\title{
Institutional Architecture For Sustainable Development (SD): A Case Study from Bangladesh, India, Nepal, and Pakistan
}

\author{
Medani P. Bhandari
}

$\mathrm{PhD}$, Professor and Deputy Program Director of Sustainability Studies, Akamai University, Hawaii, USA, International Program Director, Atlantic State Legal Foundation, NY, USA, Executive Director, Human Survival Foundation, Glasgow, UK

\section{Keshav Bhattarai}

PhD, Professor of Geography, School of Environmental, Physical \& Applied Sciences, University of Central Missouri Warrensburg, USA

\begin{abstract}
Proper institutional architecture (IA), one of the two main themes of the Earth Summit, is important for sustainable development (SD). The IA not only has global importance for governance, but also has importance for national and regional governances. Proper governance is needed in developing, monitoring and implementing policies that are needed to meet the three pillars - social, environmental and economic of SD. After the establishment of a global level institution - the United Nations Environment Program (UNEP) in 1972 as a result of the Stockholm Conference, and the Commission on Sustainable Development (CSD) in 1992 following the Rio Earth Summit - many countries have expressed their commitments to develop strong IA within their administrative network to attain the goals of SD. Arguments are that strong IA framework is needed to halt or reverse global environmental degradation. Critics, however, say that there are overlapping and competing claims than collaborating mandates between the UNEP and CSD to meet the goals of SD. Nonetheless, none has undermined the importance of IA to achieve the goals of SD. The importance of IA has increased further after the World Summit on Sustainable Development (WSSD) in 2002 to attain the goals of SD for the 21st century. However, despite the action oriented approaches of WSSD for global and regional partnerships, many countries have failed to deliver needful changes within their IA. Research scholars question if IA is not well established, how would countries meet the standard of Rio+20 for delivering SD objectives. Reviewing the status of IA from four South Asian countries - Bangladesh, India, Nepal and Pakistan - from published literature and government portals and analyzing secondary data, this paper evaluates the strengths and weakness of IA of these countries. These four South Asian countries have expressed their repeated commitments to institutionalize services needed to achieve the goals of SD, however, our analyses of the IA's performance indicators do not justify their claims.
\end{abstract}

An analysis of four major indicators - Environmental Performance Index (EPI), the Global Competitiveness Index (GPI), Human Development Index (HDI) and Multidimensional Poverty Index (MPI) - within the framework of SD suggests that all four countries have different levels of social, economic and environmental foundations. However, all countries are competing to attain international conferences, signing and ratifying major multilateral environmental agreements (MEAs), and claiming to achieve the goals of SD. Though these countries claim to have designed policies, laws, and administrative organizations to meet the requirements of MEAs, weak performance indicators suggest need for further investigation of IA performances. This investigation will reveal whether repeated commitments in papers, mere participations in various conferences, signing treaties, and creating IA to draw international aids are enough or there are other factors that inhibit countries from achieving the goals of SD.

Keywords: institution, sustainable development, biodiversity, environment conservation and management.

JEL Classification: Q001, Q50, Q56.

(C) The Authors, 2017. This article is published with open access at ARMG Publishing.

\section{Introduction}

The global focus on sustainability began in earnest with the 1980 publication of the World Conservation Strategy by the International Union for Nature and Natural Resources (IUCN). This bold statement highlighted the scope and limitations of our planet's natural resources and ecological systems. Though it presented a great scope of future development with the wise use of available resources, it also presented a sce- 
nario how humankind's current and future uses of resources would diminish the carrying capacities of our ecosystems. Though neoliberalists might disagree with the arguments of limiting carrying capacity in view of the new innovative measures, the Brundtland Commission on Sustainable Development (CSD) in 1987 has realized the possibilities of deteriorating ecosystem services if the present trend of resource consumption continues without alternatives. It even coined the term of sustainable development (SD) for the wise use of resources, so as to ensure their availabilities for future generations. The Brundtland report gained much importance in the UN Conference on Environment and Development (UNCED) in Rio de Janeiro in 1992. Agenda 21 of this UNCED emphasized much on the sustainable aspect of ecosystem services. Since then SD got more importance both in concept and practice. Today, the UN and its agencies are embedding the term SD in each of their activities as envisioned by the CSD. As members of the UN, the South Asian countries - Bangladesh, India, Nepal, and Pakistan - are actively participating in each that is emphasized by CSD. These countries have signed numbers of major binding and non-binding international agreements related to SD. For example, they have ratified biodiversity and environment conservation proposed by the UN. In line to many binding agreements, these countries have created legal instruments to sustain their domestic environments, especially since the 1972 Stockholm Conference as the vice chairs of the World Summit for Sustainable Development (WSSD) Anaedu and Engfeldt wrote:

\section{Ensuring an effective institutional framework for sustainable development at all levels is key to the realization of the goals of sustainable development. To achieve these goals and to meet the emerging challenges, the sustainable development governance architecture needs to be strengthened at the international, regional, and national levels as these are inextricably linked and mutually interdependent. There is a clear need to enhance the responsiveness of the cur- rent institutional arrangements for the full implementation of Agenda 21, bearing in mind all relevant principles, including in particular, the principle of common but differentiated respon- sibilities of States (2002:2).}

The above statement embraces the definition what Brundtland outlined in 1987 "development that meets the needs of the present without compromising the ability of future generations to meet their own needs" (p. 41). In line to the SD, the WSSD (2002) suggested to focus on six major areas, to attain global sustainability. These include: Poverty eradication; Sustainable management and conservation of natural resources; Making globalization fit with the sustainable goals; Improving governance at all levels; and Providing funding for research to find alternative means through scientific and technological innovation to sustain the development (WSSD 2002; Von Schomberg 2002). Anaedu and Engfeldt (2002) proposed for the strong institutional development at the international, national, and regional levels to improve functioning in these areas. Prior to the WSSD meeting, the UN urged that its Rio declaration signatory countries must submit a profile of their institutional strengths and weakness and should show their commitments to SD. Accordingly, Bangladesh, India, Nepal and Bangladesh submitted their institutional profiles. The main argument of this paper is whether the submission of institutional infrastructure is enough to show commitment for the SD or there are other factors that hinder the signatory countries to achieve the goals of SD.

With this brief introduction, first we present major key themes of SD as proposed by the CSD. This will be followed by country's backgrounds and their overall performances. Then we present institutional arrangements in tackling issues of sustainable development. We also review the historical legacy and cooperative practices adapted in these four countries. This will be followed by a conclusive summary and references.

\section{Key themes suggested by the Commission on Sustainable Development (CSD)}

The key themes of CSD can provide crucial guidance for decision-making in a variety of ways, for example, transforming physical and social science knowledge into manageable objects. Such a transformation not only helps in decision-making process through the calibration of sustainable SD goals, but also, they signal an early warning, if adversities are noticed in economic, social and environmental conditions. The Chapter 40 of Agenda 21 of the Rio Earth Summit 1992 calls for signatories' countries to harmonize their SD efforts at international, national, and local levels and ease the decision-making processes. Accordingly, in 1995, the CSD called upon the organizations of the UN systems to implement the key elements of the CSD. The Nineteenth Special Session of the General Assembly held in 1997 affirmed the importance of key themes of SD (as contained in para. 111 and 133.b of the Program for Further Implementation of Agenda 21). It also suggested mechanisms how to exchange information among all interested actors on research, methodological and practical activities associated with indicators of SD. In the methodology, it established a freely accessible database available to governments, provide training for capacity building at the regional and national 
levels in the use of the indicators for monitoring progress towards SD; testing of an appropriate combination of indicators and identification and assessment of linkages among the economic, social, institutional and environmental elements of SD to further facilitate decision-making processes at all levels. Some of the indicators developed by the CSD are listed in Table 1.

Table 1. Key themes suggested by Commission on Sustainable Development (CSD)

\begin{tabular}{|c|c|}
\hline Social & Environmental \\
\hline Education & Freshwater/groundwater \\
\hline Employment & Agriculture/secure food supply \\
\hline Health/water supply/sanitation & Urban \\
\hline Housing & Coastal Zone \\
\hline Welfare and quality of life & Marine environnement/corral reef protection \\
\hline Cultural heritage & Fisheries \\
\hline Poverty/income distribution & Biodiversity/biotechnology \\
\hline Crime & Sustainable forest management \\
\hline Population & Air pollution and ozone depletion \\
\hline Social and ethical values & Global climate change/sea level rise \\
\hline Role of women & Sustainable use of natural resources \\
\hline Access to land and resources & Sustainable tourism \\
\hline Community structure & Restricted carrying capacity \\
\hline Equity/social exclusion & Land use change \\
\hline Economic & Institutional \\
\hline Economic dependency/Indebtedness/ODA & Integrated decision-making \\
\hline Energy & Capacity building \\
\hline Consumption and production patterns & Science and technology \\
\hline Waste management & Public awareness and information \\
\hline Transportation & International conventions and cooperation \\
\hline Mining & Governance/role of civic society \\
\hline Economic structure and development & Institutional and legislative frameworks \\
\hline Trade & Disaster preparedness \\
\hline Productivity & Public participation \\
\hline
\end{tabular}

Source: UN-DSD 2007.

As shown in Table 1, these development indicators are grouped under four themes. Our major goal is to explore how institutional arrangements have been made and utilized in the four South Asian countries. Since there is no universal model to examine country-specific institutional architecture for SD, we analyze the countries' situation by utilizing the Governance and Environmental Performance Index (EPI); the Global Competitiveness Index (GCI) and Human Development Index (HDI) and Multidimensional Poverty Index (MPI). In addition, we also used the baseline data submitted by WSSD 2002 for the respected countries.

\section{Country status in term of SD}

A vast difference exists in economy, demography, and socio-political conditions among four countries. To compare the economic indices, we used geographical area, total population, population density, purchasing power parity (PPP) GNI/capita (US\$), GNI/capita (US\$), and annual growth GDP (\%) (Table 2).

Table 2. A brief comparative account of four countries

\begin{tabular}{|l|c|c|c|c|c|c|}
\hline \multicolumn{1}{|c|}{ Country } & $\begin{array}{c}\text { Land surface in } \\
\text { 000 sq. km.) }\end{array}$ & $\begin{array}{c}\text { Population in } \\
\text { million 2010 }\end{array}$ & $\begin{array}{c}\text { Population density } \\
\text { (per sq. km.) 2010 }\end{array}$ & $\begin{array}{c}\text { PPP GNI/capita } \\
\text { (US\$) 2010 }\end{array}$ & $\begin{array}{c}\text { GNI/capita } \\
\text { (US\$) 2010 }\end{array}$ & $\begin{array}{c}\text { Annual growth } \\
\text { GDP (\%) 2010 }\end{array}$ \\
\hline Bangladesh & 144 & 160 & 1157.83 & 1550 & 580 & 6.2 \\
\hline India & 3287 & 1181.4 & 350.61 & 3280 & 1,220 & 7.3 \\
\hline Nepal & 147 & 28.9 & 202.06 & 1180 & 440 & 5.3 \\
\hline Pakistan & 796 & 184 & 206.90 & 2680 & 1,000 & 2 \\
\hline
\end{tabular}

Source: Environmental Performance Index (EPI) (2010); World Bank (2011); Bhandari (2012). 
Table 2 indicates that in terms of GDP India ranks first among four countries followed by Pakistan and Bangladesh and Nepal. However, when comparing the Human Development Index (HDI) and Multidimensional Poverty Index (MPI) all four countries exhibit low performances (Table 3).

Table 3. HDI and MPI Index and its components

\begin{tabular}{|c|l|c|c|c|c|c|c|c|c|c|}
\hline $\begin{array}{c}\text { HDI } \\
\text { rank }\end{array}$ & \multicolumn{1}{|c|}{ Country } & $\mathrm{a}$ & $\mathrm{b}$ & $\mathrm{c}$ & $\mathrm{d}$ & $\mathrm{e}$ & $\mathrm{f}$ & $\mathrm{g}$ & $\begin{array}{c}\text { MPI } \\
\text { rank }\end{array}$ & $\begin{array}{c}\text { MPI } \\
\text { index }\end{array}$ \\
\hline 119 & India ** & 0.519 & 64.4 & 4.4 & 10.3 & 3,337 & -6 & 0.549 & 73 & 0.2962 \\
\hline 125 & Pakistan $* *$ & 0.490 & 67.2 & 4.9 & 6.8 & 2,678 & -4 & 0.523 & 69 & 0.2754 \\
\hline 129 & Bangladesh* & 0.469 & 66.9 & 4.8 & 8.1 & 1,587 & 12 & 0.543 & 72 & 0.2914 \\
\hline 138 & Nepal* & 0.428 & 67.5 & 3.2 & 8.8 & 1,201 & 12 & 0.506 & 81 & 0.3499 \\
\hline
\end{tabular}

Notes: (a) = Human Development Index (HDI) in 0-1 scale; (b) = Life expectancy at birth: Number of years a newborn infant could expect to live if prevailing patterns of age-specific mortality rates at the time of birth were to stay the same throughout the infant's life; (c) = Mean years of schooling: Average number of years of education received by people ages 25 and older in their lifetime based on education attainment levels of the population converted into years of schooling based on theoretical durations of each level of education attended; $(\mathrm{d})=$ Expected years of schooling: Number of years of schooling that a child of school entrance age can expect to receive if prevailing patterns of age-specific enrolment rates were to stay the same throughout the child's life; (e) = Gross national income (GNI) per capita (PPP US\$ 2008); (f) = GNI per capita rank minus HDI rank; and (g) = Non-income HDI value: Value of Human Development Index computed from life expectancy and education index only in $0-1$ scale; ** Medium Human Development; * Low Human Development. Similarly, MPI considers different variables and weighted through the range of deprivations that afflict a person's life at the same time in $0-1$ scale.

Source: UNDP (2010: 223-224); Alkire and Santos (2010) (Data from Multidimensional Poverty Index: 2010 and OPHI 2010).

Table 3 shows that in terms of both HDI and MPI, the conditions of all four countries are not strong at a global scale. For example, among the 169 nations used in the HDI index, India ranks $119^{\text {th }}$ (where lower rank represents better and higher rank represents worse performance), followed by Pakistan 125, Bangladesh 129 and Nepal 138 rank. Similarly, in terms of MPI Pakistan ranks $69^{\text {th }}$ followed by Bangladesh at $72^{\text {nd }}$, whereas India ranks $73^{\text {rd }}$ (below Bangladesh) and Nepal ranks $81^{\text {st }}$ among 104 countries on MPI. The lower MPI rank indicates the gap between and the rich and poor. The higher HDI of India among the four countries puts India in a better situation; however, Bangladesh precedes India in term of MPI (Allvoices 2010). These poor performances indicate that despite willingness to ratify various treaties upon the call of $\mathrm{UN}$, it is unlikely that they can achieve the goals of SD.

In the overall competitiveness, measured with reference to the strength of three categories, these four countries show poor performances. The categories include (1) basic requirements: institutions, infrastructure, macroeconomic environment and health and primary education; (2) efficiency enhancers: higher education and training, goods market efficiency, labor market efficiency, financial market development, technological readiness; market size; and (3) innovation and sophistication factors: business sophistication and innovation (WEF 2010:4-8). Among these three categories, the institutional strength is the first indicator followed by infrastructure, followed by macroeconomics, and health and education.

Table 4. Global Competitiveness Index (GCI)

\begin{tabular}{|l|c|c|c|c|}
\hline \multicolumn{1}{|c|}{ Country/Economy } & GCI 2010 Rank & GCI 2010 Score & GCI 2009 Rank & Change 2009-2010 \\
\hline Bangladesh & 107 & 3.64 & 106 & -1 \\
\hline India & 51 & 4.33 & 49 & -2 \\
\hline Nepal & 130 & 3.34 & 125 & -5 \\
\hline Pakistan & 123 & 3.48 & 101 & -22 \\
\hline
\end{tabular}

Note: There were 139 nations used in the competitiveness measurement; wherein higher rank was assigned to the best performing countries and 139 was the worst ranked in terms of performance. Similarly, the scores were 1-7, where 1 shows no competitiveness and 7 as the strongest competitiveness. For example, as shown in Table 4, India's position in the index score is only 4.33; in another word India's has achieved only 61.86 percent strength of competitiveness; Bangladesh scores 3.64; only 52 percent; Pakistan score 3.48; 49.71 percent and Nepal score of 3.34; 47.71 percent strength of competitiveness respectively (WEF 2010).

Source: WEF (2010).

Table 4 provides a general understanding of countries' inability to create institutional capacity for sustainable development (Sathaye 2006). It reveals from Table 4 that in all four countries exhibit weak in overall competitiveness, with only India gaining just above the global mean score of 3.7. Further, there are no signs of degradation; for example, within a year, Pakistan's position dropped drastically by 22 points, Nepal by 5 , 
India by 2 and Bangladesh by 1 . The competitive index provides an important framework for understanding the strengths and weaknesses of countries' Institutional Architecture for SD.

A country's institutional competitiveness can also be seen as a proxy measure of SD. It shows how well a country placed in the contemporary sustainable development millennium goals to achieve the goals of Agenda 21. WSSD's (2002) Proclamation Five asserts that economic development, social development and environmental protection are the major pillars of SD at the local, national, regional and global levels (UN 2002). Figure 1 shows basic requirements: institutions, infrastructure, macroeconomic environment and health and primary education conditions of four countries, where Pakistan ranks lowest (81), Nepal ranks 125, and Bangladesh ranks 114. In terms of infrastructure Nepal is the worst globally having the lowest rank of 139, whereas Bangladesh ranks at 133. Among all four basic requirements, India retains a good ranking; however, in the health and primary education category it ranks 104, with the score of 5.16. Despite maintaining good status among the four Asian countries, India also ranks low in the global competitiveness (Table 4).

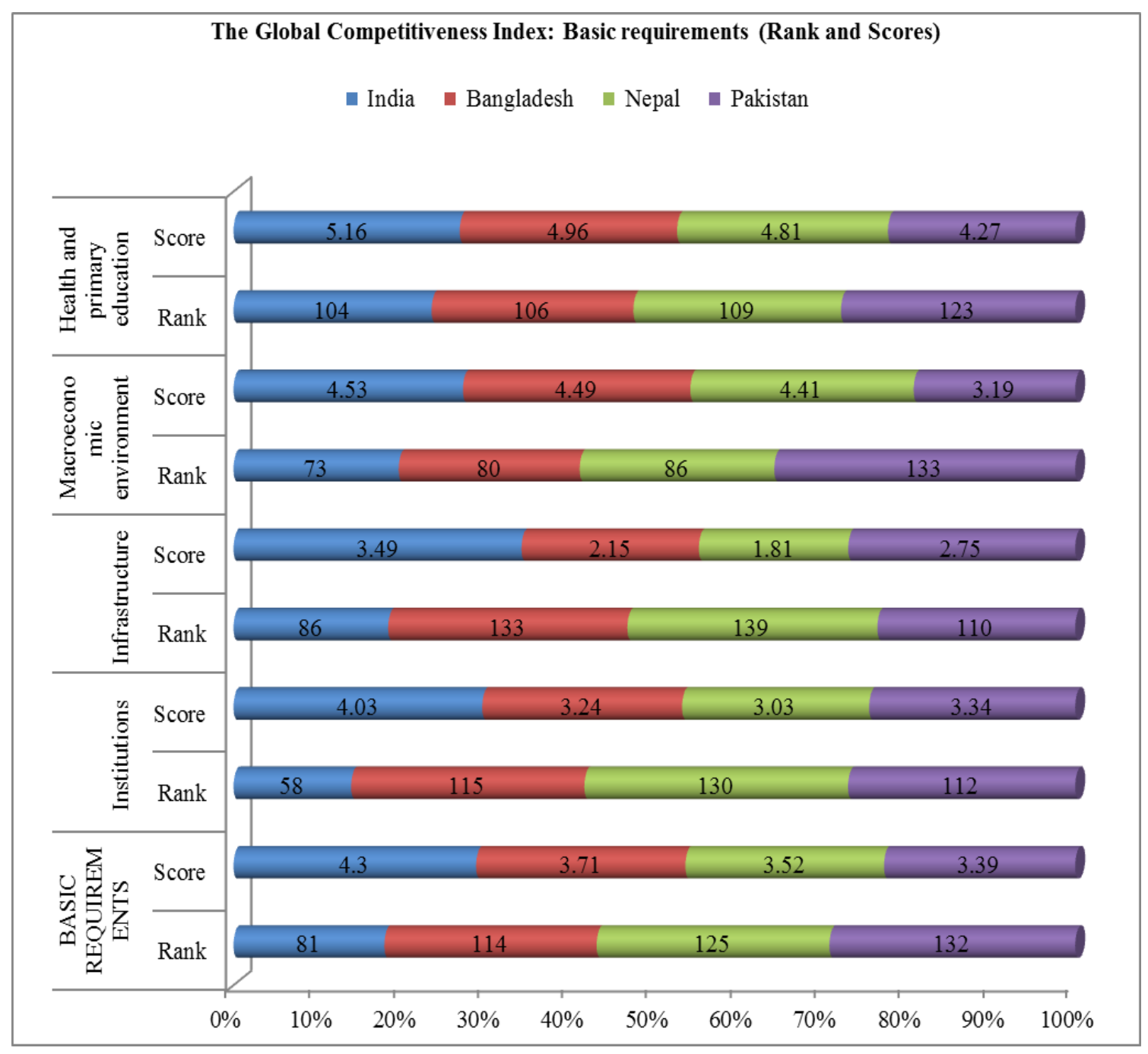

Figure 1. Global Competitiveness Index: basic requirements

Source: data compiled from the World Economic Forum (2010).

The quality of institutions has a strong bearing on competitiveness and growth as it influences investment decision-making and the organization of production including the rationalization of distribution of resources among citizens (WEF, 2010:4). Figure 2 show the level of strengths of 21 indicators among these four countries. These theme indicators include the social and economic aspects of the sustainability as prioritised by the CSD to attain the goal of SD. 


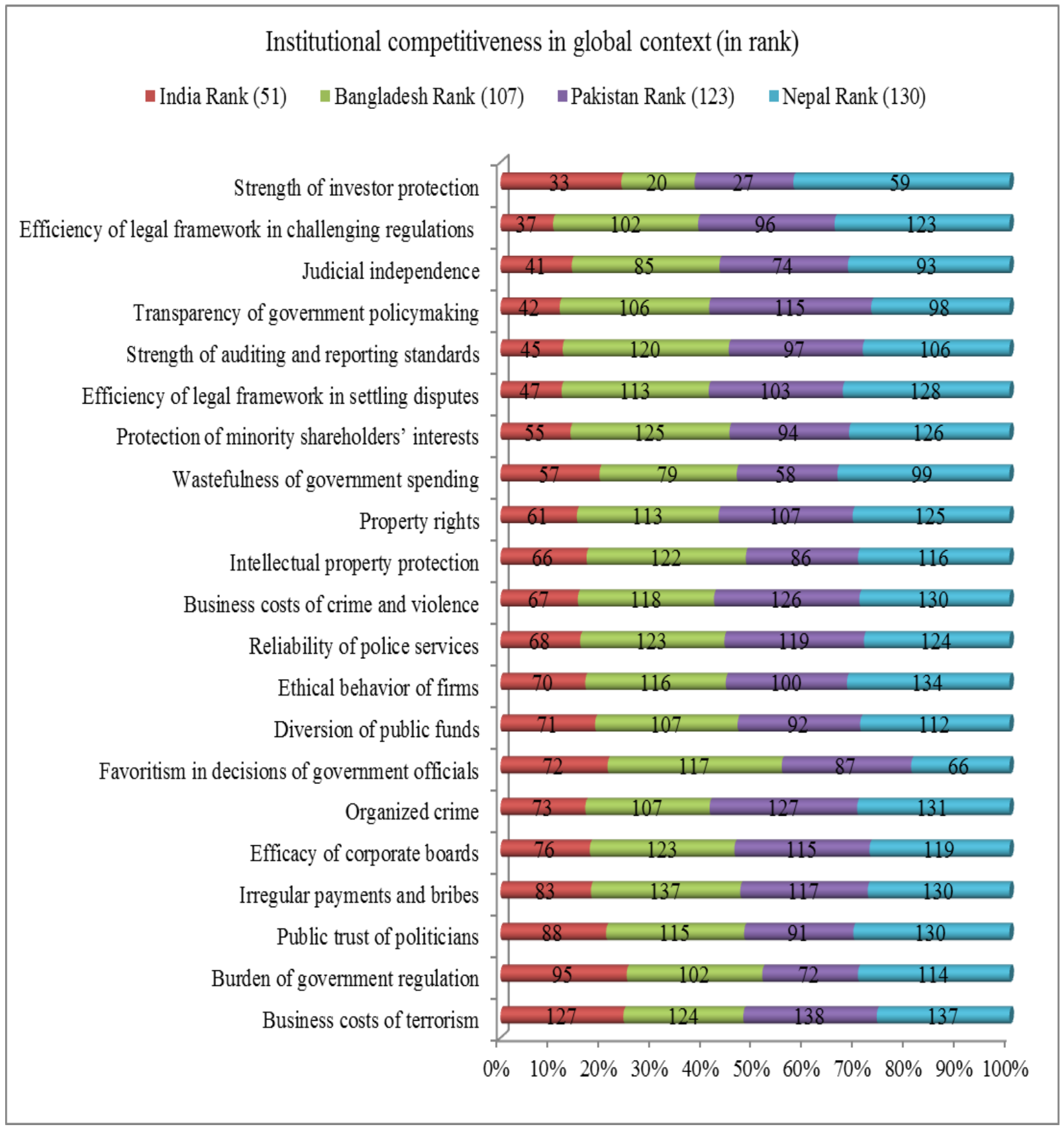

Figure 2. Institutional competitiveness of four countries in global context (in rank)

Source: data compiled from the World Economic Forum (2010).

Figure 2 indicates that in term of terrorism, Pakistan ranks $2^{\text {nd }}$ (Rank 138 among 139) and Nepal ranks $3^{\text {rd }}$ (Rank 137). Terrorism ranking is measured based on the cost a country has to contain terrorist activities. Terrorism impacts negatively on the institutional development. On burden of government regulation, Pakistan ranks 72, followed by India at 95, Bangladesh at 102, and Nepal at 114; on public trust of politicians, India ranks 88, Pakistan 91, Bangladesh 115 and Nepal 130; and on irregular payments and bribes India ranks 83, Pakistan 117, Nepal 130 and Bangladesh 137 (third worst in the world). These indicators show constrains faced by a country in institutional development.

In term of the institutional competitiveness, all four countries show a similar pattern in HDI, MPI, and GCI. However, socio-political and economic performances are not only indicators to measure how well a nation manages the environment. Figure 3 provides a contrasting picture, where Nepal, a weak performing country in terms of the HDI, MPI, GCI and competitiveness, appears as a strong performer in terms of sustainable environmental management; however, it fails in meeting the goals of SD at the global standard. 


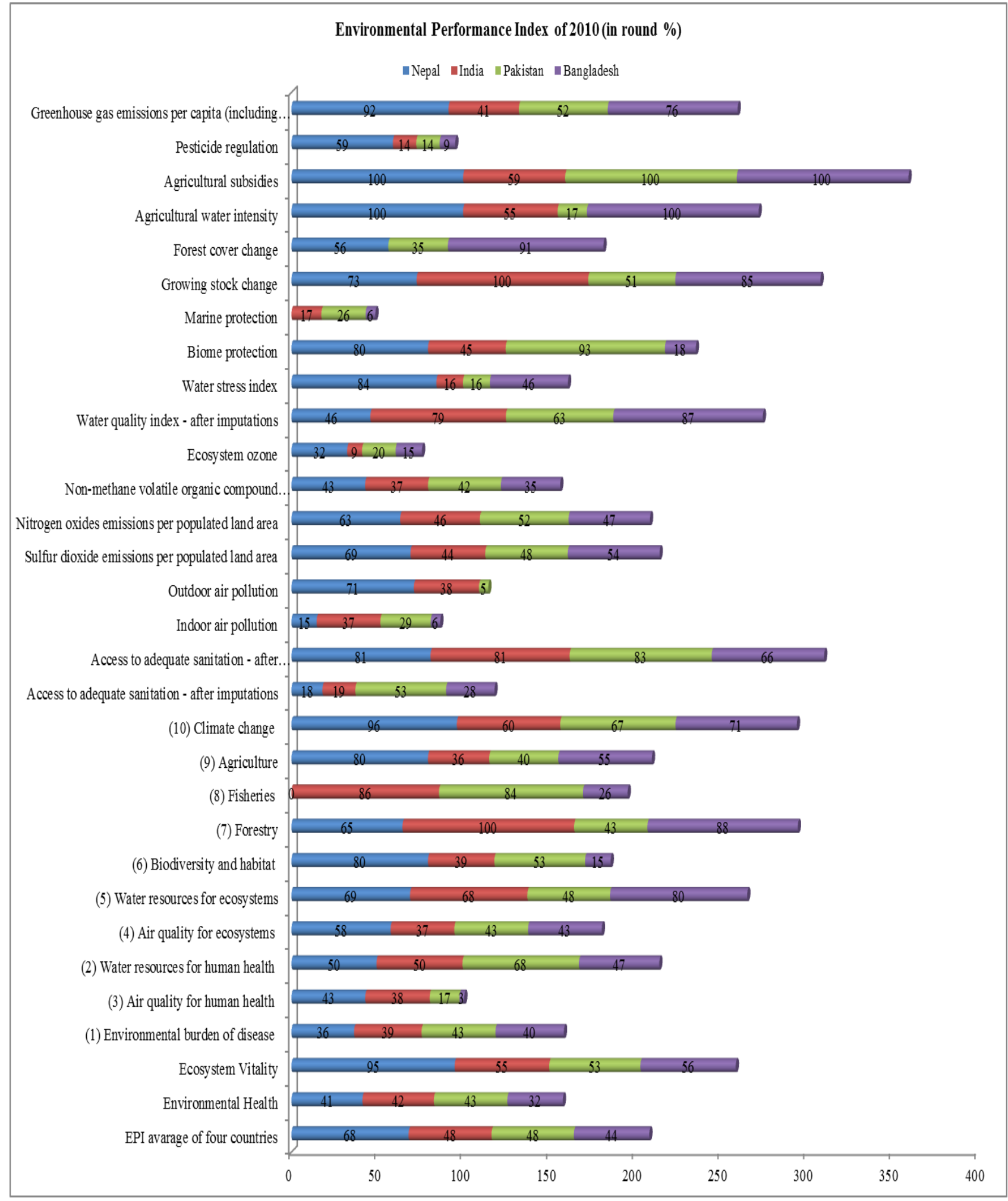

Figure 3. Environmental Performance Index

Plotted from EPI (2010) (higher values represent better performance) Note: numbers in brackets show comparative scores on the ten indicators and the other 20 show the impact factors. The higher percentage scores represent better performance.

Among the 20 major indicators used (Figure 3) Nepal shows good performance with 68.2 score, which is 4th among the Asian and Pacific region, whereas India ranks 20 with score of 48.3, Pakistan ranks 21 with a score of 48.0, and Bangladesh ranks 24 with the score of 44.0. Figure 3 indicates that countries do not perform consistently across all categories. Despite poor economic growth, Nepal has performed well even in the global context in terms of climate change with the score of 96.36 ; in terms of ecosystem vitality it scores 95.09 , 
in biodiversity \& habitat it scores 79.85 , and in agriculture it scores 79.55 , whereas in environmental burden of disease and environmental health it scored only 36.49. India demonstrates good performance in forestry management with a perfect score of 100; its fisheries management also is very good with 85.95 score (EPI 2010). In contrast Bangladesh, scores only 26.02 (worst among the four) in fisheries though fisheries constitute the major food source for this country. Nepal being landlocked is not included in the fishery category.

The above account reveals that a country's performance in meeting SD's goals depends upon the effective governance, the economic development, industrial growth, and emissions level in the atmosphere. Though Nepal performs best in term of the global climate, her good performances in this area probably are due to her poor industrial bases. As seen in the governance performance indices in the regional and the global context, Nepal ranks almost at the bottom in the competiveness index, because most of the government sectors are not working properly. A country's performance in one sector does not qualify a country in terms of performance indices. In the following paragraphs, we would like to review the countries' status in others measures of SD.

\section{Sustainable development performance}

"Sustainable development is not a matter of discrete actions on a range of development concerns pertaining to society, economy and environment. It is about finding integrated approaches that address potentially multiple impacts and benefits across the three pillars of sustainable development (social, economic and environmental) to "find new ways of balancing equity, economics and ecology". This requires not only a need to define a vision that involves open, intense and continuing dialogue with all elements in society but also long-term investment in partnerships between nation states, as well as between governments at all levels, businesses, and civil society" (GoI 2010:39). It is not possible to evaluate the performance of SD just by examining one or two components, but it is requires the evaluation of multiple factors. Of these factors, institutional set up and associated components determine the performance of SD. Therefore, we evaluated the effectiveness of institutional performances by utilizing the most commonly used term - the environmental performance index (EPI) as suggested by the World Bank (2010:1) and EPI (2010). EPI reflects a how well or how poorly a government program is being conducted and what should be done to achieve a program's objectives. We evaluated some proxy scores of (1) environmental burden of disease; (2) water resources for human health; (3) air quality for human health; (4) air quality for ecosystems; (5) water resources for ecosystems; (6) biodiversity and habitat; (7) forestry; (8) fisheries; (9) agriculture; and (10) climate change (as illustrated in Figure 3).

We also evaluated how these countries are maintaining their environmental sustainability status. To do so, we utilized the countries' position papers submitted to the WSSD in 2002. These papers were helpful to examine how these countries are faring in the preparation for Rio+20 Summit. According to the UN, each country has to submit their past performances to show how they have achieved SD goals set by the Agenda 21. In order to qualify to attend the Rio+20 Summit each country must show significant improvement in trade, industry, energy, transport and sustainable tourism. Also, countries should have performed well in the management of hazardous, solid and radioactive wastes, and must have done some activities in the development of biotechnology and capacity building to be participants of Rio+20 Summit (UN 2002:i).

Table 5 summarizes the major indicators of sustainable development incorporated in the country profiles, which also reflect their institutional architecture for sustainable development.

Table 5. Summary of the major indicators of sustainable development

\begin{tabular}{|l|c|c|c|c|}
\hline \multicolumn{1}{|c|}{ Issues / Country } & India & Pakistan & Nepal & Bangladesh \\
\hline \multicolumn{2}{|c|}{ National Decision-Making Structure } & Yes & Yes & Yes \\
\hline 1. National Sustainable Development Coordination Body & Yes & Yes & Yes & Yes \\
\hline 2. National Sustainable Development Policy & In Process & No & No & No \\
\hline 3. National Agenda 21/other strategy for SD & No & No & No & No \\
\hline 4. Local/Regional Agenda(s) 21 & Yes & Yes & Yes & Yes \\
\hline 5. Environmental Impact Assessment Law & Yes & Yes & Yes & Yes \\
\hline $\begin{array}{l}\text { 6. Major Groups involved in Sustainable Development Deci- } \\
\text { sion-Making }\end{array}$ & Yes & Yes & Yes & Yes \\
\hline $\begin{array}{l}\text { 1. Sustainable Development or Environmental education in- } \\
\text { corporated into school curricula }\end{array}$ & & & Yes
\end{tabular}


Table 5 (cont.). Summary of the major indicators of sustainable development

\begin{tabular}{|c|c|c|c|c|}
\hline Issues / Country & India & Pakistan & Nepal & Bangladesh \\
\hline \multicolumn{5}{|l|}{ National Instruments and Programs } \\
\hline 2. Sustainable Development Indicators Program & Yes & Yes & Yes & Yes \\
\hline 3. Ecolabel Regulations & Yes & Yes & Yes & Yes \\
\hline 4. Recycle/Reuse Programs & Yes & Yes & Yes & Yes \\
\hline 5. Green Accounting Program & $\begin{array}{c}\text { Yes - * } \\
\text { Municipalities }\end{array}$ & No & No & No \\
\hline 6. Access to Internet & Yes & Yes & Partial & Yes \\
\hline 7. Access to World Wide Web & Yes & Partial & Partial & Partial \\
\hline $\begin{array}{l}\text { 8. A national World Wide Web Site for Sustainable Dev. or State of } \\
\text { the Environment }\end{array}$ & Yes & Yes & Partial & Yes \\
\hline Policies, Programs, and Legislation & Yes & Yes & Yes & Yes \\
\hline 1. Combatting poverty & Yes & Yes & Yes & Yes \\
\hline 2. Changing consumption and production patterns & Yes & No & No & Yes \\
\hline 3. Atmosphere & Yes & Yes & No & Yes \\
\hline 4. Land Use Planning & Yes & No & No & No \\
\hline 5. Forest and Deforestation & Yes & Yes & Yes & Yes \\
\hline 6. Desertification and Drought & Yes & Yes & No & No \\
\hline 7. Sustainable Mountain Development & Yes & Yes & Yes & Yes \\
\hline 8. Sustainable Agriculture & Yes & No & No & No \\
\hline 9. Biological Diversity & Yes & Yes & Yes & Yes \\
\hline 10. Biotechnology & Yes & No & No & No \\
\hline 11. Oceans and Coastal Areas & Yes & Yes & No & Yes \\
\hline 12. Freshwater Management & Yes & Yes & Yes & Yes \\
\hline 13. Toxic Chemicals & Yes & Yes & Yes & Yes \\
\hline 14. Hazardous Wastes & Yes & Yes & No & Yes \\
\hline 15. Solid Wastes & Yes & Yes & No & Yes \\
\hline 16. Radioactive Wastes & Yes & Yes & No & Yes \\
\hline 17. Energy & Yes & Yes & No & Yes \\
\hline 18. Transport & Yes & Yes & No & Yes \\
\hline 19. Sustainable Tourism & Yes & Yes & Yes & Yes \\
\hline
\end{tabular}

Source: This table is framed from the country profile of India (United Nations, 2002: 114), where the latest is updated from the Government of India (2004); Government of Nepal (2003); Government of Pakistan (2000); Government of Bangladesh (2005); SAARC (2008).

Indicators presented in Table 6 justify that all four countries are committed to attain the goals of SD though performances differ among them. India shows the strongest mechanism among the four, and Pakistan ranks in second position. Bangladesh and Nepal are yet to demonstrate their performances as promised. We examine the country wide institutional performances in each country in the following paragraphs.

\section{Institutional arrangement in tackling sustainable development issues}

There is no separate umbrella institutional setup in tackling sustainable development issues in the countries of question. However, issues are covered through national bodies in each such as the national development council, national planning commission (NPC), national water resources development council, environment protection council, national commission on sustainable development, water and energy commission, and national biodiversity coordination committee.

In Bangladesh the issues of the sustainable development are guided through the National Sustainable Development Strategy (NSDS) 2007, whereas umbrella agency is the Ministry of Environment and Forests which is supposed to "ensure sustained economic growth, environmental protection and social justice which implies improvement of livelihood options of the people, reduction of poverty; ensuring wise use of natural resources, good governance and people's participation" (Government of Bangladesh 2008:1). However, the NSDS is silent that how the ministry coordinates with different agencies to obtain these goals. For example, 
the NSDS states that "the Ministry of Agriculture through the Bangladesh Agricultural Research Council (BARC) deals with productivity aspects of land. Under the same ministry, the Department of Agricultural Extension (DAE) undertakes extension of the research outcomes of the institutes mentioned above. The Department of Environment (DoE) under the Ministry of Environment and Forest (MoEF) deals with aspects of land pollution" (Government of Bangladesh 2008:67). The report reveals the complexity of sustainable development but silent on how practically policy functions.

In India, the report on Sustainable Development Perspectives notes that "Sustainable development is achieved through optimizing gains from several variables, rather than maximizing those from a single one. This requires government departments, by convention sectorally organized, to work together, or in some cases as a single multi-disciplinary authority" (Government of India 2010:9), and accepts that there is not yet such institutional frame is setup. In so far, the Ministry of Environment and Forests is the focal agency in addressing the issues on SD.

In Nepal, the main agencies responsible for SD include the Ministry of Forests and Soil Conservation (MFSC) and Ministry of Environment, Science, and Technology (MEST) and other lines agencies.

In Pakistan, the Ministry of Environment and Forests looks after the environmental affairs (FAO 1997; Government of Pakistan 2000; Indian National Science Academy 2001; Government of Nepal 2004; Biswas and Islam 2004; Government of India, Ministry Of Environment and Forests 2007; ICIMOD 2007; Riaz 2010). However, in all four countries there are no institutions or agencies in operation specialize in sustainable development and management, regardless of external support to obtain the goals of sustainability.

For example, these countries also receive help from the South Asian Association for Regional Cooperation (SAARC) to attain the goal of SD. SAARC aims to enhance institutional capacity not only within these four countries but among all its eight-member countries. It also coordinates with the Bay of Bengal Initiative for Multi Sectoral Technical and Economic Cooperation (BIMSTEC). BIMSTEC is a subregional mechanism for selected South-South East Asian Member Countries. These countries include Bangladesh, Bhutan, India, Myanmar, Nepal, Thailand, and Sri Lanka). In addition, SAARC also coordinates with Asian Disaster Reduction and Response Network (ADRRN), IUCN regional office, UN Agency Regional Office, and several other international organizations to address environmental issues of South Asia. SAARC has also established Regional Institutions to strengthen the regional collaboration and networks, including SAARC Meteorological Research Centre (Climate change in Asia 2007:191) and Agricultural Centre (SAC) Dhaka, Tuberculosis Centre (STC), Kathmandu, Documentation Centre (SDC), New Delhi, Human Resources Development Centre (SHRDC), Islamabad, Coastal Zone Management Centre (SCZMC), Maldives, Information Centre (SIC), Nepal, Energy Centre (SEC), Pakistan Disaster Management Centre (SDMC), India, Forestry Centre (SFC), Bhutan and SAARC Cultural Centre (SCC) (Biswas and Islam 2004; ICIMOD 2007; Riaz 2010). Likewise, regional institutions such as International Centre for Integrated Mountain Development (ICIMOD) and the IUCN headquartered in Kathmandu Nepal have been helping South Asian countries to attain SD goals. Additionally, other institutions such as Asia-Pacific Network for Global Change Research (APN), International Foundation for Science (IFS), the United Nations University (UNU), the South-South-North (SSN), South-South-North Adaptation Project Protocol (SSNAPP) also work as regional institutions to implement the goals of SD. Many of these institutions are operating under the existing legacies in those countries which were colonized previously, while in countries without any colonial experience, these organizations are operating with new structures (Bhandari, 2017, 2012, 2012a).

\section{Legacy and cooperative practice in pursuit of sustainability}

Bangladesh, India, and Pakistan have inherited the conservation legacy from as former British colonies. Nepal was never colonized, but its conservation programs and policies were also influenced from the Indian forestry. Among these four countries, India is ahead in the institutionalization and management of forest resources. Nepal has a relatively recent history of utilizing modern tools in forest management (SAARC 2008).

\footnotetext{
${ }^{1}$ (SMRC is very important regional organization in South Asia that concentrates primarily on the research aspects of weather forecasting and monitoring; its research areas include weather prediction and compiling climatological information; and in addition to monitoring weather phenomena, SMRC is also engaged in developing a networking system among the Member States.
} 
However, in recent years it has prepared and implemented several instruments ${ }^{2}$ and has demonstrated model work in the conservation of nature through citizen participation, despite political upheavals and tensions. Bangladesh, India, and Pakistan have attempted to implement Nepal's model, but have had limited success (Bhandari, 2011). There is no explanation in this regard why the same approach works successfully in one country and not in other despite having similar cultures, traditions, economic conditions, and topography.

In terms of modern conservation practice all four countries have similar histories. Conservation efforts largely began after the 1972 United Nations Conference on the Human Environment in Stockholm. The Conference put much emphasis on forest and environmental conservation. From 1972 onward, all four countries took major steps toward environmental management, including forestry and biodiversity. Their governments also initiated policies, rules and regulations to address global biodiversity issues. In policy formations India, has been pioneer. For example, in 1972, the Wild Life Protection Act was passed in India which provides for the constitution of a Wild Life Advisory Board, regulation of hunting of wild animals and birds, laying down procedures for declaring the areas as sanctuaries and national parks, and regulation of trade in wild animals (Government of India, 2004). Similarly, to address environmental issues, the Water (Protection and Control of Pollution) Act was passed in 1974, which opened the window for the establishment of central and state pollution control boards for the prevention and control of water pollution. The act seeks to control pollution primarily through standards to be laid down by the boards and the consent orders issued by them. Stiff penalties are imposed for violation. The boards are given ample powers for investigation and inspection, to take samples, and to establish laboratories for analyzing the samples. Likewise, the Water Pollution Control Act and Air (Protection and Control of Pollution) Act were passed in 1981 in India (Government of India 2004; SAARC 2008), setting standards to control air pollution. Following the footsteps of India, Nepal, Pakistan and Bangladesh ${ }^{3}$ also introduced legal instruments to address environmental problems.

In all four countries, there is a participatory approach to development planning, decision making and implementation and monitoring processes. Bangladesh has the strongest NGO network and presence, followed by India and Pakistan. Nepal does not have as large number of NGOs as the other three countries; however, Nepali NGOs have a strong presence in most of the social sectors. All four countries have signed numerous humanitarian and environment-related international treatises, conferences, and agreements (Table 7, see in Appendix).

Similarly, these countries also have maintained memberships of over 65 international organizations. India became the member of the United Nations (October 30, 1945) and the Non-Aligned Movement of UNEP. She is a leading member of the South Asian Association for Regional Cooperation (SAARC). Similarly, Pakistan entered the UN on September 30, 1947; Nepal on December 14, 1955 and Bangladesh on September 17, 1974. All countries have signed several international conservation binding treaties, conventions and conferences. These countries host many international organizations (IOs) (Government of Bangladesh 2005, 2007; Government of India 2004, 2010; Government of Nepal 2003, 2009; Government of Pakistan 2000, 2003, 2009, and 2010); SAARC 2008, 2010). Several IOs have their headquarters in these countries and these IOs are involved in environment and forest conservation, human rights, education, women empowerment, agricultural development, and green industrial development.

Despite the memberships of several international organizations and showing the commitments to the international treaties and conventions, these countries are falling behind to achieve the goals of sustainable development. Among several reasons, the lack of competitive capacity to tackle the poverty, and increasing inequality have hindered these countries from achieving the desired goals of SD. The performance indices of various indicators such as HDI, MPI, GCI, and MPI suggest that these countries are far behind in achieving the goals of sustainable development. The roles of institution become stronger only when socioeconomic

\footnotetext{
2 i.e. National Forestry Plan 1976; National Conservation Strategy 1988; Forestry Sector Policy 1989; Nepal Environmental Policy and Action Plan 1993; Master Plan for the Forestry Sector 1989-2010; Nepal Biodiversity Strategy 2002; and environment Regulations and Guidelines like Environmental Impact Assessment Guidelines for the Forestry Sector 1995; Buffer Zone Regulations 1996; Environment Protection Regulations 1997; Buffer Zone Management Regulation 1996 etc.

${ }^{3}$ In Nepal, policies for the conservation and protection of forests and biodiversity have emphasized decentralization and community participation; in Bangladesh policies focus on increasing tree cover in agricultural and urban landscapes. Similarly, in India many initiatives have addressed joint forest management and resolving tenure issues with a Forest Rights Act. Pakistan has not been as successful as the other countries and recently, made an appeal for UNFCCC assistance in conducting a National Economic, Environment and Development Study to engage in mitigation and adaptation activities. Among the four Nepal, Bangladesh and Pakistan have been benefiting most from the IUCN in preparing conservation policies. While India has the most advanced policies, it lacks effective implementation. Having a strong knowledge-based system of environmental policy, India has been helping Nepal prepare policies and providing financial support for project implementation (Kant et al. 2010).
} 
conditions can meet the citizens' aspiration (North 1981). When there is poverty and hunger as the rule of natural, one needs to survive first. The countries of this study are still at the first tier of development; for example, $17 \%$ of the total population in Bangladesh, 33.5\% in India, 24\% in Nepal, and 33.5\% Pakistan are still living with the < \$1/day (ADB-ICIMOD 2006; SDPI 2006; UNEP-DA 2008). To attain the goal of sustainability it is necessary to fulfill the citizens' aspiration which is only possible when these countries will be able to stabilize the population growth, eradicate poverty and hunger, able to eradicate common diseases, and fill the gap of gender inequality. Poverty and inequality are the functions of resource scarcity and these scarcities weaken the institutions as Warleigh rightly puts:

"Institutions act as forums in which actors cooperate, argue, deliberate and make the decisions which eventually constitute the policy. Institutions can also shape the values and belief systems of those who work within them. As a result, they influence not just what actors do, but often also how they view the world in which they live as well as the people and ideas with which they must engage in order to realize goals" (2002: 4).

In the South Asian context in general and with reference to these four countries in particular, citizens lack minimum standards for living due to poverty. In this rampant poverty, it is unlikely that any formal or informal institutions can bring the desired outcome by framing the Institutional Architecture to achieve the goal of Sustainable Development (SD).

\section{Conclusion}

In this paper, we explored how institutional arrangements have been made and utilized in the four countries of South Asia. An analysis of available facts revealed that there is no universal model to examine country-specific institutional architecture to achieve the goal of sustainable development. Thus, we analyzed the countries' situation by utilizing the Governance and Environmental Performance Index (EPI); the Global Competitiveness Index (GPI), Human development Index (HDI) and Multidimensional Poverty Index (MPI). This study shows that these countries are not being able to frame institution to address the issues of SD because of the inherent poverty. Though these countries have made necessary efforts, yet these efforts have not been able in moving forward to muster sustainability goals.

The institutional framework for sustainable development covers a spectrum of formal and informal networks and arrangements. An effective institutional architecture is the key to the implementation of sustainable development. A strong institutionalization is required in all socio-economic sectors to help in decision-making processes. Available records revealed have poor HDI and MPI and competitiveness indices. Since sustainability is a function of all integrated work, the major hurdles these countries facing today are poor social and economic conditions. Because of large gaps in terms of the HDI, MPI, competitiveness, and environmental sustainability performance, these countries are not equipped to institutionalize the environmental, social and economic pillars in their institutional architecture to accomplish the goals of sustainable development. Though these countries have expressed their commitments to craft rules and regulations within their boundaries and they are willing to sign-up in needed agreements, they still need to increase their capabilities to monitor and timely reporting practices, promote sustainable livelihoods, and reduce dependency on natural resources.

In achieving SD goals, it is essential that country should be able in achieving the overall competitiveness, which is pillared by the social, economic, environmental and institutional development indicators. We argue that to address the overall themes of SD and to obtain the desire outcome it is mandatory that country fulfills at least basic requirement of competiveness. These include proper macroeconomic environment, health and primary education for its citizens' wellbeing.

\section{Acknowledgement}

We acknowledge the input of Dr. Nimisha Bhattarai, who helped us for gathering information on biodiversity information. We thank to Ms. Prajita Bhandari for insightful comments, and input. We would also like to thank to Prameya and Manaslu specially for their positive comments on the language pattern of this paper. We would also like to thank the reviewer panel for their input and comments.

\section{References}

1. Asian Development Bank (2004). Development Indicators Reference Manual; Concepts and Definitions; Economics and Research Department, Development Indicators and Policy Research Division, the Asian Development Bank (ADB), Manila, Philippines. Available at http://www.adb.org/Statistics/pdf/Reference-Manual.pdf. 
2. ADB-ICIMOD (2006). Environment Assessment of Nepal: Emerging Issues and Challenges. ADB, Manila, ICIMOD, Kathmandu.

3. Alkire, Sabina and Santos, Maria Emma (2010). Multidimensional Poverty Index: 2010 Data. Oxford Poverty and Human Development Initiative. Available at www.ophi.org.uk/policy/multidimensionalpoverty-index/. Accessed on 5/20/2011.

4. Allvoices (2010). India ranks 119th in Human Development Index 2010-UN. Allvoices, San Francisco, CA 94104. Available at http://www.allvoices.com/contributed-news/7238938-india-ranks-119th-inhuman-development-index-2010un. Accessed on 5/20/2011.

5. Anaedu, O. and Engfeldt, Lars-Goran (2002). Sustainable Development Governance. Paper prepared for consideration in the Second Week of the Third Session of the Preparatory Committee for WSSD.

6. Bhandari, Medani P. (2017). The Pedagogical Development of the International Organization and Organizational Sociology Theories and Perspectives, in Douglass Capogrossi (Ed.). Educational Transformation: The University as Catalyst for Human Advancement. Xlibris Corporation, USA (in press).

7. Bhandari, Medani P. (2012). Environmental Performance and Vulnerability to Climate Change: A Case Study of India, Nepal, Bangladesh, and Pakistan. Climate Change and Disaster Risk Management. Series: Climate Change Management, pp. 149-167. Springer, New York / Heidelberg, ISBN 978-3-64231109-3.

8. Bhandari, Medani P. (2012). Exploring the International Union for the Conservation of Nature (IUCN's) National Program Development in Biodiversity Conservation: A Comparative Study of India, Pakistan, Nepal, and Bangladesh. Sociology - Dissertations. 73. Available at http://surface.syr.edu/soc etd/73.

9. Biswas, Aruna and Islam, Safiqul, A.N.M. (2004). Regional Workshop on Science \& Technology Statistics organized by: UNESCO Institution for Statistics, Ministry of Science and Information \& Communication Technology (MOSICT), Bangladesh.

10. CIA (2010). The World Fact Book, Government of the United States of America, The Central Intelligence Agency, Office of Public Affairs, Washington, D.C. https://www.cia.gov/library/publications/the-world-factbook/geos/bg.html (Bangladesh) https://www.cia.gov/library/publications/the-world-factbook/geos/in.html (India) (accessed on 11/17/10) https://www.cia.gov/library/publications/the-world-factbook/geos/np.html https://www.cia.gov/library/publications/the-world-factbook/geos/pk.html (Pakistan).

11. Climate change in Asia (2007). Background Paper Impacts, vulnerability and adaptation to climate change in Asia, Beijing, China 11-13 April 2007, This paper was commissioned by the secretariat of the United Nations Framework Convention on Climate Change and prepared by Mozaharul Alam, Atiq Rahman, Mariam Rashid, Golam Rabbani, Preety Bhandary, Suruchi Bhadwal, Murali Lal, and Moekti Handajani Soejachmoen. In some parts of the document the secretariat introduced modifications. http://unfccc.int/files/adaptation/methodologies_for/vulnerability_and_adaptation/application/pdf/unfccc asian workshop background paper.pdf.

12. Cotter, B. and Hannan, K. (Environs Australia) (1999). Our Community Our Future: A Guide to Local Agenda 21, Commonwealth of Australia, Canberra.

13. Desai, B. H., Oli, K. P., Yang Yongping, Chettri, N. and Sharma, E. (2011). Implementation of the Convention on Biological Diversity: A retrospective analysis in the Hindu Kush-Himalayan countries, ICIMOD, Kathmandu.

14. Environmental Performance Index (EPI) (2010). (repared by the Yale Center for Environmental Law and Policy (YCELP) Yale University and Center for International Earth Science Information Network (CIESIN), Columbia University, Available at: http://epi.yale.edu and distributed by the NASA Socioeconomic Data and Applications Center at http://sedac.ciesin.columbia.edu/es/epi/.

15. EPI (2010). Environmental Performance Index, Summary for Policymakers, Yale Center for Environmental Law and Policy, CT and Columbia University in collaboration with the World Economic Forum, Geneva, Switzerland, Joint Research Centre of the European Commission, Ispra, Italyhttp://epi.yale.edu/epi-2010.pdf; http://epi.yale.edu/Countries/Bangladesh; http://epi.yale.edu/ Countries/Nepal?grouping_id=2; http://epi.yale.edu/Countries/India?grouping_id=2; http://epi.yale.edu/ Countries/Pakistan?grouping_id=2; http://www.ciesin.columbia.edu/repository/epi/data/2010EPI_ summary.pdf.

16. European Union-EU (2009). Study on understanding the causes of biodiversity loss and the policy assessment framework, in the context of the Framework Contract No (DG ENV/G.1/FRA/ 2006/0073, Specific Contract No-DG.ENV.G.1/FRA/2006/0073) (prepared by Allister Slingenberg, Leon Braat, Henny van der Windt, Koen Rademaekers, Lisa Eichler, Kerry Turner) for European Commission, Di- 
rectorate-General

for

Environment,

Brussels

http://ec.europa.eu/environment/enveco/biodiversity/pdf/causes_biodiv_loss.pdf

17. FAO (1997). Asia-Pacific Forestry Sector Outlook. Study Working Paper Series Working Paper No: APFSOS/WP/32, Country Report - Nepal, Forestry Policy and Planning Division, Rome and Regional Office for Asia and the Pacific, Bangkok. Available at ftp://ftp.fao.org/docrep/fao/W7719E/W7719E00.pdf.

18. Government of India-GoI (2010). Inputs for the Secretary-General's Report to the Second Preparatory Committee of UNCSD Ministry of Environment and Forests, Government of India. Available at http://www.uncsd2012.org/files/response-member-states/Questionnaire-Email-submission-India (Attachment).pdf.

19. GoI (Government of India) (2010). India's major donors and collaborative partners in addressing the environment and climate change issues. Available at http://www.karmayog.com/lists/foreigndonors.htm. Accessed on 05/02/2011.

20. --- (2004). India's Initial National Communication to the United Nations Framework Convention on Climate Change. New Delhi: Ministry of Environment and Forests.

21. --- (2007). Protection, Development, Maintenance and Research in Biosphere Reserves in India. Guidelines and Proforma. Government of India, Ministry Of Environment and Forests, CGO Complex, Lodi Road, New Delhi-110003. Available at www.envfor.nic.in October, 2007. http://envfor.nic.in/divisions/csurv/BR_Guidelines.pdf. Accessed on 04/23/2010.

22. Government of Bangladesh (2005). National Adaptation Program of Action (NAPA), Final Report. November 2005, Ministry of Environment and Forest Government of the People's Republic of Bangladesh. Available at http://www.moef.gov.bd/bangladesh\%20napa\%20unfccc\%20version.pdf. Accessed on $05 / 29 / 2011$.

23. --- (2007). Climate Change and Bangladesh. Climate Change Cell Department of Environment Government of the People's Republic of Bangladesh, Dhaka. Available at http://www.bdresearch.org.bd/home/climate_knowledge/cd1/pdf/Bangladesh\%20and\%20climate\%20ch ange/Climate\%20change\%20impacts\%20,vulnerability.

24. Government of Bangladesh (2008). National Sustainable Development Strategy (NSDS). Department of Environment Ministry of Environment and Forests Government of the People's Republic of Bangladesh, Dhaka.

25. Government of Nepal (2002). Nepal Biodiversity Strategy, Ministry of Forests and Soil Conservation, Government of Nepal, Kathmandu. Available at http://www.mfsc.gov.np/upload/4_Biodiversity_Strategy.pdf. Accessed on 05/10/2011.

26. --- (2004). Initial National Communication to the Conference of the Parties of the United Nations Framework Convention on Climate Change, Ministry of Population and Environment, Kathmandu. Available at http://unfccc.int/resource/docs/natc/nepnc1.pdf.

27. --- (2009). Nepal Major Activities on Climate Change Regime, Government of Nepal, Ministry of Environment, Science and Technology (MoEST), Singhdarbar, Kathmandu, Nepal. Available at www.most.gov.np/np/downloads/cc\%20activities.doc. Accessed on 05/26/2011.

28. Government of Pakistan (2000). National Report of Pakistan on the Implementation of United Nations Convention to Combat Desertification (UNCCD). Ministry of Environment, Local Government and Rural Development, Government of Pakistan, Islamabad (April 2000). Available at http://www.unccd.int/cop/reports/asia/national/2000/pakistan-eng.pdf.

29. --- (2003). Pakistan's Initial National Communication on Climate Change. Government of Islamic Republic of Pakistan Ministry of Environment, Islamabad, Pakistan. Available at http://unfecc.int/resource/docs/natc/paknc1.pdf. Accessed on 06/03/2011.

30. --- (2009). Implementation of the UU Framework Convention on Climate Change (UNFCCC) in Pakistan (presented by Ahmad Jan Malik Section Officer (NCS-1), Ministry of Environment, Islamabad. Available at http://www.ap-net.org/docs/14th seminar/malik.pdf. Accessed on 06/03/2011.

31. --- (2010). Labor Policy 2010. Government of Pakistan, Islamabad. Available at http://www.lmis.gov.pk/publications/LPP.pdf.

32. ICIMOD (2007). Protected Areas, Ramsar Sites, and World Heritage Sites. Nepal Biodiversity Resource Book. ICIMOD, MOEST, GoN, Kathmandu, Nepal. 
33. ICIMOD-UNEP (2009). Inception Workshop Report, Kailash Sacred Landscape Conservation Initiative Kathmandu, Nepal, International Centre for Integrated Mountain Development (ICIMOD), Nepal, United Nations Environment Program (UNEP), Kenya.

34. Indian National Science Academy (2001). Pursuit and promotion of science: The Indian experience. Publication of Indian National Science Academy, Published by S. K. Sahni, Executive Secretary, Indian National Science Academy, Bahadur Shah Zafar Marg, New Delhi-110001. http://www.insaindia.org/INSA-book.pdf. Accessed on 04/22/2011.

35. OPHI (2010). Oxford Poverty \& Human Development Initiative. Oxford Department of International Development, Queen Elizabeth House, University of Oxford. Available at http://www.ophi.org.uk/policy/multidimensional-poverty-index/. Accessed on 05/20/2011.

36. SAARC (2008). SAARC Statistics Year Book Part-1. SAARC Secretariat, Kathmandu. Available at http://www.bbs.gov.bd/WebTestApplication/userfiles/Image/Test1/SAARC_Part-1.pdf.

37. --- (2010). Area of Cooperation-Environment, SAARC Secretariat, Kathmandu. Available at http://www.saarc-sec.org/areaofcooperation/cat-detail.php?cat_id=54. Accessed on 05/30/2011.

38. Sathaye, Jayant, Shukla, P. R. and Ravindranath, N. H. (2006). Climate change, sustainable development and India: Global and national concerns. Current Science, 90(3), 314-325.

39. SDPI (2006). Sustainable Industrial Development / National Environmental Quality Standards. Sustainable Development Policy Institute, Islamabad Available at http://www.sdpi.org/research_Programme/environment/sustainable_industrial_development.htm\#6 (accessed on 06/03/2011).

40. The World Economic Forum (2010) The Global Competitiveness Index 2010-2011 rankings and 20092010 comparisons, World Economic Forum 91-93 route de la Capite, CH - 1223 Cologny/Geneva, Switzerland and World Economic Forum USA, 3 East 54th Street, 17th Floor, New York, NY 10022, USA http://www.weforum.org/en/index.htm

41. Treaties Office Database of the European Commission (2010). Database of the European Commission, Belgium. Available at http://ec.europa.eu/world/agreements/default.home.do.

42. UNDP (2010). Global Human Development Report 2010. Human Development Report Office, New York.

43. United Nations (2002). Country Profile of Government of India for World Summit for Sustainable Development (WSSD). United Nations, New York.

44. --- (2002). Country Profile of Government of Bangladesh for World Summit for Sustainable Development (WSSD), United Nations, New York.

45. --- (2002). Country Profile of Government of Nepal for World Summit for Sustainable Development (WSSD), United Nations, New York.

46. --- (2002). Country Profile of Government of Pakistan for World Summit for Sustainable Development (WSSD), United Nations, New York.

47. --- (2002). Implementing Agenda 21 Report of the Secretary-General. Commission on Sustainable Development acting as the preparatory committee for the World Summit on Sustainable Development Second session 28 January-8 February. 2002.E/CN.17/2002/PC.2/7.

48. UN-DSD (United Nations Division for Sustainable Development) (2007). Indicators of Sustainable Development: Guidelines and Methodologies (3rd Edition). United Nations, New York Available athttp://www.un.org/esa/sustdev/natlinfo/indicators/guidelines.pdf.

49. United Nations Department of Economic and Social Affairs (UNDESA) (2011). The Transition to a Green Economy: Benefits, Challenges and Risks from a Sustainable Development. Perspective Report by a Panel of Experts* to Second Preparatory Committee Meeting for United Nations Conference on Sustainable Development Prepared under the direction of Division for Sustainable Development, UNDESA United Nations Environment Program UN Conference on Trade and Development, New York. Available at http://www.uncsd2012.org/rio20/content/documents/Green\%20Economy_full\%20report\% 20final\%20for\%20posting\%20clean.pdf.

50. United Nations Environment Program and Development Alternatives - UNEP-DA (2008). South Asia Environment Outlook 2009: United Nations Environment Program (UNEP), South Asian Association for Regional Cooperation (SAARC) and Development Alternatives (DA) UNEP, SAARC and DA. Available at http://www.saarc-sec.org/userfiles/SAEO\%202009.pdf.

51. Warleigh, A. (2002). Introduction: institutions, institutionalism and decision making in the EU, Understanding European Union Institutions. A. Warleigh (ed.). Routledge, London and New York, UK and USA. 
52. World Bank (2010). World Development Report, Development and Climate Change. The International Bank for Reconstruction and Development, The World Bank, Washington, DC.

53. World Bank Data (2011). Multiscale data portal. World Bank, Washington, DC. Available at http://data.worldbank.org/data-catalog. Accessed on 05/07/2011.

\section{Appendix}

Table 7. Major multilateral environment agreements (MEAs) ratified by India, Pakistan, Bangladesh and Nepal

\begin{tabular}{|c|c|c|c|c|}
\hline \multirow{2}{*}{ Content } & \multicolumn{4}{|c|}{ Ratified / Signed } \\
\hline & Bangladesh & India & Nepal & Pakistan \\
\hline $\begin{array}{l}\text { Plant Protection Agreement for the South East Asia and } \\
\text { Pacific (as amended), } 1956\end{array}$ & 1974 & 1956 & 1965 & 1969 \\
\hline $\begin{array}{l}\text { Convention on Wetlands of International Importance } \\
1971\end{array}$ & 1994 & 1982 & 1988 & 1975 \\
\hline $\begin{array}{l}\text { Convention for the Protection of World Cultural and } \\
\text { Natural Heritage } 1972\end{array}$ & 1983 & 1977 & 1978 & 1972 \\
\hline $\begin{array}{l}\text { Convention on International Trade in Endangered } \\
\text { Species of Wild Fauna and Flora, } 1973\end{array}$ & 1981 & 1982 & 1975 & 1976 \\
\hline $\begin{array}{l}\text { Bonn Convention on Migratory Species of Wild Ani- } \\
\text { mals } 1979\end{array}$ & 2005 & 1983 & & 1987 \\
\hline $\begin{array}{l}\text { Vienna Convention for Protection of the Ozone Layer } \\
1985\end{array}$ & 1990 & 1987 & 1994 & 1992 \\
\hline $\begin{array}{l}\text { Montreal Protocol on Substances that Deplete the } \\
\text { Ozone Layer } 1987\end{array}$ & 1990 & 1992 & 1994 & 1987 \\
\hline $\begin{array}{l}\text { Agreement on the Network of Aquaculture Centers in } \\
\text { Asia and the Pacific, } 1988\end{array}$ & 1992 & 1992 & 1990 & 1991 \\
\hline $\begin{array}{l}\text { Basel Convention on Transboundary Movements of } \\
\text { Hazardous Wastes and their Disposal } 1989\end{array}$ & 1993 & 1992 & 1997 & 1994 \\
\hline $\begin{array}{l}\text { United Nations Framework Convention on Climate } \\
\text { Change (UNFCCC) } 1992\end{array}$ & 1994 & 1994 & 1994 & 1994 \\
\hline Convention on Biological Diversity (CBD) 1992 & 1994 & 1994 & 1994 & 1994 \\
\hline $\begin{array}{l}\text { United Nations Convention to Combat Desertification } \\
1994\end{array}$ & 1994 & 1994 & 1994 & 1997 \\
\hline $\begin{array}{l}\text { UN Convention to Combat Desertification in those } \\
\text { Countries Experiencing Serious Drought and/or Deser- } \\
\text { tification, Particularly in Africa, } 1994\end{array}$ & 1994 & 1996 & 1997 & 1994 \\
\hline Kyoto Protocol to the UNFCCC 1997 & 2005 & 2005 & 2005 & 2005 \\
\hline $\begin{array}{l}\text { Rotterdam Convention on the Prior Informed Consent } \\
\text { Procedure for Certain Hazardous Chemicals and Pesti- } \\
\text { cides in International Trade } 1998\end{array}$ & 1998 & 1998 & 2007 & 2005 \\
\hline Cartagena Protocol on Biosafety to the CBD 2000 & 2004 & 2003 & 2001 & 2001 \\
\hline $\begin{array}{l}\text { Stockholm Convention on Persistent Organic Pollutants } \\
2001\end{array}$ & 2001 & 2006 & 2007 & 2001 \\
\hline
\end{tabular}

Source: Treaties Office Database of the European Commission (2010); ICIMOD-UNEP 2009; Desai et al., 2011. 